\title{
Mathematics Teachers' Perception about Problem Solving Task: Case Study in SMA 4 Lahat
}

\author{
Cecil Hiltrimartin \\ Mathematics Education Department \\ FKIP Unsri \\ Palembang, Indonesia \\ hiltrimartincecil@yahoo.com
}

\begin{abstract}
This present study aims to know mathematics teachers' perception of a problem-solving task. Two mathematics teachers of a Senior High School in Lahat are chosen using purposive sampling technique as the subject of the study. Semistructured interview method is used to collect data. The data are analyzed using content analysis method. The study reveals that the teachers stated that problem-solving task was important to be given to their students to make them see the connection between mathematics and daily life. To be able to solve problems, the teachers stated that their students had to understand mathematics concept. Polya's problem-solving techniques can be used to help students solve problems. A problem is stated as the problem-solving task only if it is not a routine problem. Not all mathematics problems can be categorized as the problem-solving task. As a matter of fact, the teachers found some difficulties in developing routine problems into the problem-solving task, so problem-solving tasks were found only in particular mathematics topics. This study indicates that problems teachers use in their instruction are very important and can be used as a tool to enhance student's high thinking ability.
\end{abstract}

Keywords-Perception, Problem-solving task.

\section{INTRODUCTION}

Problem-solving skills are important in everyday life, not only in mathematics but in all areas. Society needs capable problem solvers. We are in the age where technology like computers and calculators perform many of the basic calculation which frees us to spend more time on problems that are more complex. Strong mastery of mathematics is required to master and invent technology in the future [3].

The objectives of learning mathematics in primary and secondary education unit [3] is for students to have the ability to solve problems that include the ability to understand the problem; designing a mathematical model, complete model and interpret the acquired solutions; communicate ideas with symbols, tables, diagrams, or other media to clarify situation or problems; and have an attitude to appreciate the usefulness of mathematics in life: curiosity, attention, interest in learning mathematics, tenacious attitude and confidence in problem solving.

Problem-solving is appropriate and important in mathematics school. This is because the learning objectives and learning procedures of problem-solving are very important in society needs. The study finds indications that the problemsolving strategies learned in the mathematics class in a few special cases can be transferred or applied in problem-solving in life. Older students who are accustomed to being confronted on the issue and try to solve mathematics problem solving have fast and creative response [4]. Unfortunately, at the international level, Indonesia is at a low level for the category of students' ability in resolving questions of problem-solving. This is demonstrated by the results of the study of The Programme for International Student Assessment (PISA).

Based on PISA's technical report, the PISA 2012 study [5] showed that less than one percent of Indonesian students could answer the questions in complex problem situations which require mathematical modeling, reflection, conceptualization, generalization, and reasoning skills. Furthermore, TIMSS 2011 study showed that only two percents Indonesian students could work with high-level questions or reasoning level. Only $43 \%$ of them could answer the low-level question (knowing type questions) whereas the International median in knowing skills was 75\% (Mullis, et al., 2012, p. 114). Indonesia students can only use procedures, formulas, and basic algorithms. It is revealed that Indonesia's students are relatively good in solving problems such as routine, but very low to solve problems related to justification or proof, problem-solving, finding generalizations or conjecture, and finding the relationship between the data or facts. The poor result is one of reflective matter for changing Indonesian curriculum from KTSP to Kurikulum 2013.

Reference [8] argues that the problem-solving learning is an action conducted by the teacher to make his/her students to be motivated to accept the challenges (problems) and direct them to the process of solving the problems. This implies the role of teacher's attitudes and perceptions towards solving problems become the deciding factor of the problemsolving learning implementation.

As in [3], perception is the ability of a person to organize an observation: the ability to differentiate, the ability to classify, and the ability to focus the next interpretation. Therefore, a person may have a different perception of the same object. This is possible due to the difference in terms of the information s/he may have and different point of view. Further as in [13] suggests that the concept of perception is a 
cognitive process, where one gives the meaning on the environment.

Mathematics teacher's perception of problem-solving task referred to in this article is the process of providing information about the meaning of problem-solving task obtained either from knowledge teachers ever received or from the experience when they teach. The information, for example, is the definition of problems, the characteristics of problem-solving problems, examples of problem-solving, distinguishing problem-solving problems and not a problemsolving, and other matters related to problem-solving.

Reference [2] stated that a high school mathematics teacher in Palembang has a positive attitude towards mathematics problem-solving learning. About $91.4 \%$ expressed a positive attitude towards component of problems and problem solving; around $8.58 \%$ expressed a negative attitude. However, the teachers are still likely to have the perception that problem-solving problems are application problems. Nevertheless, application problem is limited to training students' ability to translate the situation of the problem into a mathematics problem, does not improve students' problem solving [10]. In addition, the questions usually used in the process of learning problem-solving were routine questions, not problem-solving questions [6]. This makes students are not yet accustomed to working on the problem-solving task.

From the research results above, it can be concluded teacher's positive attitude toward problem-solving in learning can enhance students' problem-solving capabilities. However, it is questionable why teachers are still using the application problems and routine problems, rather than problem-solving. This happens because of the difference of mathematics teachers' perceptions toward problem-solving. This paper presents strategy formulated for best practices in teaching and learning mathematical problem solving for students of secondary schools in Indonesia. This research will specialize in the problem-solving task. In particular, the research question is what is teachers' perception of problem-solving task?

A focus on problem-solving seems to be a key component of mathematics teaching and learning. There are various definitions of problem-solving; these have been limited for the purpose of the paper. Lovin and Van de Walle define $a$ problem by citing the definition of Hiebert et all "any task or activity for which students have no prescribed or memorized rules or methods, nor is there a perception by students that there is a specific correct solution" Another definition used for the purpose of the study is given by Kantowski: A task is said to be a problem if its solution requires that an individual combines previously known data in a way that is new. If he can immediately recognize measures that are needed to complete the task, it is a routine task (or a standard task or an exercise) for him within the problem-solving process, the lesson begins with the teachers posing a problem question or story, which contextualizes the learning, and then afterwards concepts and procedures are derived and understood by students.
Students should be engaging in tasks posed by the teacher, which allow them to engage in the mathematics that they are expected to learn through interactions, and struggle with the mathematics, by "using their ideas and their strategies" Additionally, at-risk students' success has been attributed to a more hands-on, project-based approach to curriculum involving increased student choice, flexibility, and connections with students' everyday lives.

\section{METHODS}

This research is classified in qualitative research which describes the meaning of problem-solving from teacher's point of view. Hence, the focus of the research in this article is the perception of mathematics teacher SMA 4 Lahat about the problem-solving task.

The subject of this research is chosen based on not standard interviews of mathematics teachers at SMA No. 4 Lahat. This is done because the sampling technique used was purposive sampling technique, sampling with certain considerations.

In this study, data collection technique is an interview. The interview is the semi-standard interview with guidelines of points of the questions to be asked. However, during the interview, the questions can develop but still focus on the research problem. Validity is measured in this research by a test of teacher's credibility, which is done by way of observation of teacher's persistence and improvement of reference materials used.

\section{RESULTS AND DISCUSSION}

Two mathematics teachers in SMAN 4 Lahat are chosen using purposive sampling technique as the subject of the study. The subjects are obtained from the non-standard interview with five mathematics teachers. From the interview, it is known that only two teachers (Sarah and Cila) who once or often use problem-solving in learning; and they state willingness to get involved in this research.

In the first interview, the researchers asked about the definition of mathematics problem-solving, the characteristics of problem-solving problems, examples of problem-solving, distinguishing problem-solving problems and not a problemsolving, and other matters related to problem-solving such as steps and strategies to solve problem-solving, assessment of problem-solving, and constraints when using problem-solving in learning. However, in this first interview, the results obtained are only the definition of problem-solving task, characteristics, and examples of the problem-solving task. Problem-solving definition according to Sarah is a task that cannot be directly answered by the students because it takes other knowledge that can be used to solve the problem. While according to Cila, problem-solving is a task that students never meet before and they do not directly know in understanding the problem.

Furthermore, the characteristics of the problem-solving task according to Sarah and Cila are in Table 1: 
TABLE I. THE CHARACTERISTICS OF PROBLEM-SOLVING TASK

\begin{tabular}{|c|l|}
\hline Subject & \multicolumn{1}{|c|}{ Characteristics of Problem Solving Task } \\
\hline Sarah & $\begin{array}{l}\text { 1. In completing the problem-solving, students need } \\
\text { the ability or other knowledge. }\end{array}$ \\
\hline Cila & 2. Problem-solving is non-routine task \\
\hline & $\begin{array}{l}\text { Questions are unpredictable, not the questions } \\
\text { usually given in class. }\end{array}$ \\
& $\begin{array}{l}\text { 2. Students cannot directly solve the problem. } \\
\text { Questions have many ways to solve. }\end{array}$ \\
\hline
\end{tabular}

Then, the subject is asked to give an example of problemsolving in Fig.1

Fig. 1. Examples of problem-solving of Sarah

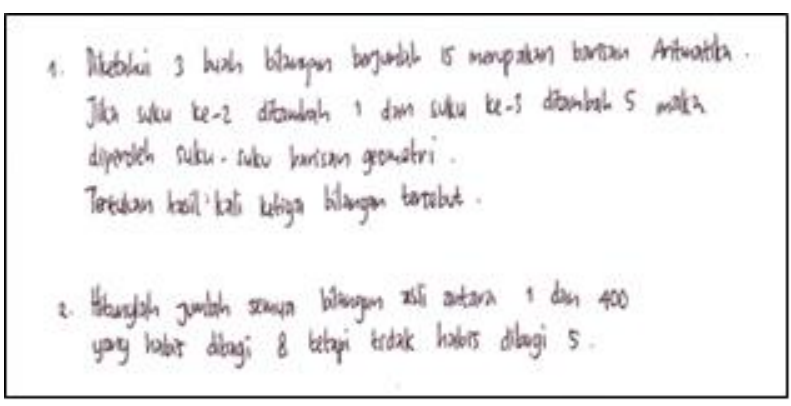

Fig. 2. Examples of problem-solving of Cila

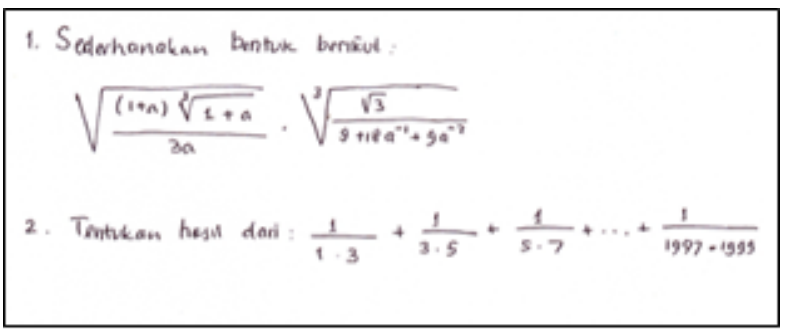

The answer of the teacher in the interview about constraints in problem-solving benefits from the use of problem-solving, steps to solve math problem solving, and learning how to assess problem-solving is still unclear. Therefore, the researchers do the second interview. The following results were obtained at the second interview.

In using the problem-solving at the time of learning, both of the subjects have the constraints shown in table 2 .

\section{TABLE II. CONSTRAINTS EXPERIENCED BY THE RESEARCH} SUBJECTS

\begin{tabular}{|c|c|c|}
\hline Subject & \multicolumn{1}{|c|}{ Constraints } \\
\hline Sarah & $\begin{array}{c}\text { Difficulties in developing the material to be the } \\
\text { problem-solving task. } \\
\text { National Standard Competency examination use } \\
\text { procedure routine task, not the problem- } \\
\text { solving task. } \\
\text { Abundance materials in the curriculum with } \\
\text { limited time. }\end{array}$ \\
\hline Cila & $\begin{array}{c}\text { Students are unfamiliar with problem-solving } \\
\text { problems especially analyzing; students are } \\
\text { more familiar with routine problems. } \\
\text { Problem-solving cannot be used on any } \\
\text { material. } \\
\text { It takes more time to solve one problem-solving } \\
\text { than one routine problem. }\end{array}$ \\
\hline
\end{tabular}

Although there are many constraints the teachers experienced when using problem-solving task, both the subject feel the benefits from the use of problem-solving in learning. According to Sarah, the teacher can assess to what extent students understand the materials taught. That's why; Sarah more often gives problem-solving task in a quiz. In the quiz, students solve the problems individually. So, the answers are varied that we can see each of students' ability to solve the problem. Unlikely, according to Cila, the benefits using problem-solving in learning is students can train solving problems.

Furthermore, according to Sarah, steps of problem-solving include students should understand the problem, plan what will be done to solve the problem, implement the plan for example using a formula, substitute the formula. This is why in the assessment of the problem-solving, Sarah prefers the process of finding results than the final result. Similarly, according to Cila, steps of problem-solving are first, students should understand the meaning of the question, next determine a plan, and then execute the plan.

In conducting the assessment of problem-solving, Cila prefers process than the final result of problem-solving. According to Cila, the teacher needs to see how the students think and their steps in solving the problems. Therefore, although the form of the questions given is multiple choice or objective, Cila often told students to do it in essay way.

From the interviews, it is obtained the idea of mathematics teacher perception towards problem-solving. The teacher's perception regarding the definition of problem-solving is a task of which solution and answer indirectly can be known by students. Students should own the ability and knowledge to solve problem-solving questions. If a child is exposed to a mathematical problem and s/he directly knows how to finish it properly, the given problem cannot be categorized as problemsolving [12].

Furthermore, teachers' perceptions regarding the characteristics of problem-solving math task are as follows:

a. The question procedures are not usual (nonroutine). These characteristics correspond to the activities in which problem-solving Polya.

b. The question requires some ways to solve.

c. The question is challenging students to solve. Students must understand the problem before determining the steps or strategies to solve problem-solving.

One of the characteristics of problem-solving is the question is challenging the mind [10]

In giving examples of problem-solving, the teachers take problems from books or from the internet and sometimes modify in accordance with the requirement. The teachers face difficulties when being asked to make own problems. This happens because the teachers are still likely to have the perception that the problem-solving can only be used for certain materials. Because there are some materials that must use the routine procedure, for example, just substituting into the formula. Meanwhile, the matter of solving the problem is a task of the procedure is not routine. 
In addition, time also becomes constraints experienced by teachers in providing problem-solving to students. According to Cila, it takes more time to solve one problem-solving than one routine problem. Reference [8] stated that ... A question would be a problem only if the question shows that there is a challenge that can't be solved by a procedure routine which is already known by students, then to solve a problem takes a relative longer than the process of solving the routine problem.

Whereas, the abundance materials in the curriculum with limited time to teach makes the teachers think twice to provide problem-solving. They are afraid there will be some materials are not yet taught due to examination. However, according to Sadiq, a mathematics teacher of can start the lesson by asking the 'problem' which is quite challenging and interesting for the students. Students and teachers then together solve the problem while discussing theories, definitions or mathematical formulas.

\section{CONCLUSION}

The conclusion from this study is that the perception of mathematics teacher of SMA Negeri 4 Lahat about the problem-solving task is teachers still use problem-solving questions only for certain materials. Some constraints the teachers face are the teachers have difficulty in developing a routine task to become a non-routine task; the students are not used to solve problem-solving problems, and it takes more time to solve problem-solving problems than it takes a task of routine.

Accordingly, the teachers expressed their perceptions about solving problems task that the problem helps students to think at higher levels. Thus, this gives an indication that the perception of teachers is very important to improve their teaching and enhance students learning in problem-solving mathematics.

\section{REFERENCES}

[1] Adithya, Y. (2012.). Implementasi model pembelajaran matematika Knisley dalam upaya meningkatkan kemampuan penalaran matematis siswa SMA. Bandung: Universitas Pendidikan Indonesia.

[2] Andesta, E. (2012). Sikap guru matematika SMA negeri di Palembang terhadap pemecahan masalah. Inderalaya: FKIP Universitas Sriwijaya.

[3] Badan Standar Nasional Pendidikan. (2006). Standar Isi untuk Satuan Pendidikan Dasar dan Menengah. Jakarta: Badan Standar Nasional Pendidikan.

[4] Indriati, Hartono, Y., \& Hiltrimartin, C. (2009). "Penerapan model pembelajaran cooperative tipe STAD dengan soal-soal pemecahan masalah pada mata pelajaran matematika di SMA Negeri 6 Palembang". Jurnal Pendidikan Matematika,, 3(1), 45-53.

[5] OECD. (2014). PISA 2012 Results: What Students Know And Can Do Student Performance in Mathematics, Reading, And Science (Vol. 1). PISA: OECD Publishing.

[6] Pratiwi, I. R. (2012). "Pembelajaran pemecahan masalah di SMA Negeri 15 Palembang". Palembang: Universitas Sriwijaya.

[7] Sarwono, \& Wirawan, S. (2010). Pengantar psikologi umun. . Jakarta: Raja Grafindo Persada.

[8] Shadiq, F. (Performer). (2004). Penalaran, pemecahan masalah dan komunikasi dalam pembelajaran matematika. Diklat Instruktur/Pengembang Matematika SMP Jenjang Dasar, Yogyakarta.

[9] Sugiyono. (2011). Metode penelitian pendidikan. Bandung: Alfabeta.

[10] Sumardyono. ( 2007). Pengertian dasar problem solving. Retrieved from

http:p4tkmatematika.org/file/problemsolving/PengertianDasarProblemS olving_smd.pd.

[11] Sumardyono. (2007). Hambatan dan kesulitan dalam menyelesaikan masalah matematika”. . Retrieved from http:p4tkmatematika.org/file/problemsolving/HambatanProblemSolving _smd.pdf.

[12] Suryadi, D. (2011). Pemecahan masalah matematika. Retrieved from http://file.upi.edu/Direktori/FPMIPA/JUR_PEND_MATEMATIKA/195 802011984031-DIDI_SURYADI/DIDI-15.pdf.

[13] Winardi. (2000). Kepemimpinan dalam Manajemen. Jakarta: Rineka Cipta. 